\title{
Regulating Research: The Origins and Institutionalization of Research Ethics Committees in Sweden
}

\author{
Helena Tinnerholm Ljungberg \\ Post doc.; IMM - Institute of Enviromental Medicine, Karolinska \\ Institute, Nobels väg 13, 17165 Solna, Sweden \\ Affiliated researcher; Department of History of Science and Ideas, \\ Uppsala University, 75126 Uppsala, Sweden \\ helena.tinnerholm.ljungberg@ki.se / helena.tinnerholm.ljungberg@idehist.uu.se
}

\begin{abstract}
The year 1966 saw the birth of Sweden's first formal Research Ethics Committee (REC) at the medical university Karolinska Institute (KI). In the following years other ethical committees were institutionalized, coordinated by a working group steered by the Swedish Medical Research Council (sMRC). Research ethical issues of a principled nature were also discussed by the Ethics Delegation of the Swedish Society of Medicine (sSM). Between 1966 and 1975, around 500 research proposals were assessed by REC s in Sweden, and the medical community started to follow certain protocols when preparing applications for ethical review. This paper traces the origins and early development of the REC system in Sweden and offers an analysis of their practices, discussions, and assessments through the reading of meeting protocols and correspondence between central actors. The aim is to sketch out how and why the system of research ethics committees emerged, became institutionalized, and developed in Sweden from the 196 os to the early 198 os. This paper connects to the recent empirical turn in historical research on medical research ethics and regulations, by focusing on how the insiders, i.e., the medical community, reacted to new demands of ethical review. The analysis illustrates how the medical researchers interacted with transnational funders, the Patients Association, a broader public, governmental authorities, and parliamentary politics when developing the Swedish REc system.
\end{abstract}




\section{Keywords}

research ethics - ethics committees - medical research - regulation - Sweden

\section{Introduction}

In February 1966, William H. Stewart, the Surgeon General of the United States sent a memo to the Karolinska Institute (KI), the prestigious Nobel-awarding medical university in Stockholm, Sweden. ${ }^{1}$ The memo stated that all ongoing and future research projects funded by the United States' Public Health Service (PHS) had to be reviewed by a local ethics committee. This new requirement sparked intense activity at the Karolinska Institute, where the medical faculty promptly formalized Sweden's first Research Ethical Committee (REC). Over the next few years this type of ethical review system was adopted by all medical faculties at the Swedish universities. On the national level, the Swedish Medical Research Council (SMRC), a governmental agency financing research, set up a working group to coordinate the efforts in the field. Similarly, the Swedish Society of Medicine (SSM), a professional organization for physicians, organized a special Ethics Delegation to deal with medical ethical issues. In this article, these organizations and their members play a central part.

Previous research on the origins of the Swedish ethics committees is scarce, ${ }^{2}$ but has shown that the 196os was a decade of rapid development in both medicine and in research ethics. The aim of this paper is to sketch out how and why the system of research ethics committees emerged, became institutionalized, and developed in Sweden from the 1960s to the early 1980s. I argue that the Swedish medical community was initially receptive to the new demand for ethical review prior to the commencement of research. Thereafter, however, the same professional community was successful in restricting external involvement and warding off legal regulation of medical research involving

1 Surgeon general, PHs, to the heads of institutions conducting research with public health service grants, 8 February 1966, A1:1, Karolinska Institutets forskningsetiska kommittéers arkiv 1967-2003 (hereafter: KIFKA), Karolinska Institutets arkiv (hereafter: KIA), Solna.

2 There are some exceptions, even though quite a few of them have been written in close connection to parliamentary reports or relied on such reports to outline the history of ethics committees; see David Hoff, "Varför etiska kommittéer?" (PhD thesis, Lund University, 2003); Niels Lynöe, Mellan cowboyetik och scoutmoral: medicinsk forskningsetik i praktiken (Stockholm, 1999); Bengt Erik Eriksson and Per Månson, Den goda tanken: om etik och moral iforskning med människor (Stockholm, 1991); and Birgitta Forsman, Forskares frihet: Om makt och moral (Lund, 2004). 
humans. This was accomplished partly by the creation of several different but coordinated organizational bodies to deal with research ethical issues, and partly by engaging in the political policy processes. Even though demands for more external control and public transparency were voiced by politicians very early on, it was not until the 1970s that review by committee of all research projects (regardless of funder) became mandatory, and it was not until 2004 that Sweden saw its first legal regulations of ethical review practices in relation to medical experiments on humans.

Internationally, the last decade has seen a spate of interest in contextualized empirical research on RECs in various national contexts. ${ }^{3}$ This new generation of researchers have problematized earlier assumptions about the institutionalization of research ethics being the result of increased "outsider control" (such as bioethicists driven by emancipatory ideals) over medical research. ${ }^{4}$ Rather, they have highlighted the role of "insider control" in the formation of the new REC system, ${ }^{5}$ or have striven to deemphasize the preoccupation with insiders and outsiders in order "to focus instead on the political functions that the practice of ethics by committee historically has been imagined to fulfil in the governance of human experimentation." ${ }^{6}$ We can also see a shift in interest away from "research scandals" as the premier force of change, towards an interest in continuity, stability and gradual development. ${ }^{7}$ Furthermore, researchers in this field have focused their attention on the ways in which national REC systems have been influenced by international developments via institutional isomorphism. ${ }^{8}$ There is a risk, however, in assuming that institutional isomorphism is always at work, or that it is always at work in the same way (e.g., in the form of "coercive isomorphism" whereby some organizations pressure others

3 Adam Hedgecoe, "A Form of Practical Machinery': The Origins of Research Ethics Committees in the UK, 1967-1972," Medical History, 53 (2009): 331-350; idem, "Scandals, Ethics, and Regulatory Change in Biomedical Research," Science, Technology \& Human Values, 42 (2017): 577-599; Laura Stark, Behind Closed Doors: IRBs and the Making of Ethical Research (Chicago, IL, 2012); Noortje Jacobs, "Ethics by Committee: Governing Human Experimentation in the Netherlands, 1945-2000" (PhD thesis, Maastricht University, 2018).

4 Stark, Behind Closed Doors; Jacobs, "Ethics by Committee," 8-11.

5 Stark, Behind Closed Doors, 8; see also the editorial by Jacobs and Tinnerholm Ljungberg in this special issue.

6 Jacobs, "Ethics by Committee," 12.

7 Hedgecoe, "Scandals, Ethics, and Regulatory Change."

8 Hedgecoe, "A Form of Practical Machinery"; idem, Trust in the System: Research Ethics Committees and the Regulation of Biomedical Research (Manchester, 2020); see also the editorial in this special issue. For the origin of the concept of institutional isomorphism, see Paul J. DiMaggio and Walter W. Powell, "The Iron Cage Revisited: Institutional Isomorphism and Collective Rationality in Organizational Fields," American Sociological Review, 48 (1983): 147-16o. 
to comply with their own standards or norms). To avoid what Adam Hedgecoe has termed "pseudo-isomorphism" - the danger of assuming that all REC s are just the same ${ }^{9}$ - this paper accounts for the specific trajectory of their emergence in Sweden. By attending to the details of the process and highlighting the national idiosyncrasies, we try to answer the call for more carefully contextualized empirical research in this field.

The analysis is based on material from both the medical community (archival material, debates, and articles in medical journals) and the national political arena (parliamentary debates, motions, interpellations, committee reports, and policy documents). In some instances, debates in national newspapers have been included to indicate what the discussion may have looked like to the broader public. The focus is on the period between the early 196os and the middle of the 1970s, from the formalization of the first ethics committee up until the point when the SMRC decided that all research on humans should be reviewed by an ethics committee. The period also roughly corresponds in time with the Declaration of Helsinki from 1964 and its first revision (in Tokyo) in 1975, when review by committee was first included as a recommendation to protect human research subjects.

\section{Experiments on Humans: the Early Swedish Reception of International Debates}

In the twentieth century, two international policies on biomedical research on humans loom larger than the rest. First, the Nuremberg "Doctor's trial" of Nazi physicians which resulted in the Nuremberg Code. Second, the well-known Declaration of Helsinki from 1964, an international code for medical ethics developed by the World Medical Association. The Declaration of Helsinki is still in use, although in a revised form. In the 1975 revision in Tokyo, it was added that research projects including human subjects ought to be reviewed by independent expert committees. ${ }^{10}$ How these international guidelines were received and discussed by physicians in the Swedish medical journal Svenska Läkartidningen/Läkartidningen illustrates some of the central values in the debates of the time. ${ }^{11}$ In this section, I will give some examples of the

9 Hedgecoe, "A Form of Practical Machinery"; idem, Trust in the System.

10 The Declaration of Helsinki, first revision from 1975.

11 The journal changed its name from Svenska Läkartidningen to Läkartidningen during the period of interest here. 
articulations of these values and provide contextual background on transnational funding and influences in the 196os.

The Nuremberg Code and some of the publications on research ethics by the American whistleblower Henry K. Beecher were presented and discussed in the professional journal for Swedish doctors Svenska Läkartidningen in 1962, in order to stimulate a debate. ${ }^{12}$ In the article, Peter Heimann, a Gothenburgbased surgeon, found it "remarkable" that "attacks from the outside" had targeted experiments on animals more often than those on humans. ${ }^{13}$ The Nazi experience, it was argued, highlighted the need to "define the borders between permissible and impermissible experiments on humans" and to teach young physicians about research ethics. ${ }^{14} \mathrm{~A}$ few years later, the Declaration of Helsinki was published and was introduced in an editorial in Läkartidningen. The declaration appeared not to pose any challenge to the Swedish medical society, according to the journal. On the contrary, it was claimed that the declaration ("fortunately") was in line with "norms that we in Scandinavia have fully accepted for a long time.".15

The editorial also trailed an upcoming article that would discuss the future possibility of making consultations with a group of, for example, senior physicians, as part of the process of setting up new research projects including experiments on human subjects. ${ }^{16}$ This article was written by Gustav Giertz, at the time a senior physician at the Karolinska Hospital, and later the head (for more than ten years) of the ssm's Ethics Delegation. ${ }^{17}$ Giertz aired his concerns about the medical community's ethical knowledge and discussed a more collective approach towards research on human subjects. Giertz implied that Swedish researchers needed more ethical guidance, and that the Declaration of Helsinki might be a step in the right direction. Interestingly, his article was heavily influenced by religious sentiments. Giertz opened by stating that "Sweden is a Christian society" and claimed that most doctors "say we want to defend Christian ideals". 18 Elaborating on the consequences of grounding medical ethics in Christian values, Giertz argued that "... the inviolability of

12 Peter Heimann, "Experiment med människor: Medicin med och utan humanitet randanmärkningar till debatten om humanförsökens villkor," Svenska Läkartidningen, 59 (1962): 2364-2376. Translations from Swedish to English are mine unless stated otherwise.

13 Ibid., 2374.

14 Ibid., 2376.

15 “Den kliniske forskarens dilemma," Läkartidningen, 62 (1965): 258-259, here $25^{8}$.

16 Ibid., 259.

17 Gustav Giertz, “Läkaretik och klinisk forskning," Läkartidningen, 62 (1965): 838-847. This article was based on a lecture held at the SsM.

18 Ibid., 838 . 
life, is grounded in faith [...]. Without this faith, respect for human dignity and democracy becomes endangered."19 While speaking from a Protestant standpoint, Giertz explicitly drew on the Roman Catholic Church's "more precise norms concerning medical practices" as worthy ideals. ${ }^{20}$ Fearing, however, that neither the individual researchers' Christian commitments nor the existing laws were sufficient to stave off abuse, Giertz welcomed the Helsinki declaration.

Giertz also offered his view of the status of medical ethics in Sweden. While he felt that the principles of the Helsinki declaration were generally observed, he warned that "we are on the slide $[\ldots]$ in some places, one is more or less unconsciously accepting the idea that some individual sacrifices cannot be avoided, if medical science shall progress and be a blessing for future generations." ${ }^{21}$ To counteract this tendency, Giertz suggested measures like ensuring that the heads of clinics gave pre-approval to any planned research, and that associations for senior physicians at larger hospitals should set up boards to serve as a consulting group in unclear cases or when heads of clinics wanted further advice. ${ }^{22}$ Medical journals and research financiers were also urged to withdraw their support from ethically dubious research. Great significance was also accorded to the scientific quality of the research and the utility of its results. ${ }^{23}$ These restrictions, however, were not the only items on Giertz's agenda. While arguing for regulatory intervention, he stressed the value of academic freedom and the importance of maintaining public trust in the medical profession. Both Giertz and the aforementioned editorial that announced his article concluded by citing the British Medical Research Council's comment on the Helsinki declaration. The citations' main message was that future medical progress was dependent on how well the medical community handled these matters and managed to maintain the high public trust it currently enjoyed. ${ }^{24}$

These debates illustrate some of the central values that featured in the medical ethical debate in the 196os: public trust, academic freedom, and the protection of research subjects. New international guidelines such as the Declaration of Helsinki were welcomed and described as already being adhered to by Swedish physicians. The medical community was also keen on making distinctions between unethical research being performed in other places and the

19 Ibid.

20 Ibid., 839 .

21 Ibid., 846.

22 Ibid.

23 Ibid., 841.

24 Ibid., 847; “Den kliniske forskarens dilemma," 258-259. 
notion that in Sweden researchers in general already made sound judgements. This manoeuvre of distinguishing between ethical behaviour at home and displacing the problem of unethical research to other places or times was common in the UK and elsewhere; often there were distinctions drawn such as that between our ethical medical research and the Nazi experiments during World War II. ${ }^{25}$

Even though the general notion within the medical community was that Swedish medical researchers were not ethically out of line, there was an openness towards making research ethics a more collective process. Already in 1965 , an informal advisory group had been founded at the Karolinska Hospital. ${ }^{26}$ In accordance with Giertz's ideas in Läkartidningen, the group consisted of senior professors. The group was influenced by the experiences of the Swedish physician and endocrinologist Rolf Luft, who had worked in the US in the early 196os. There, Luft had encountered a local ethics committee at a medical university and had gotten advance notice of the National Institute of Health's (NIH) plans. ${ }^{27}$

In the 196os, it was not uncommon for researchers like Luft to travel between Sweden and the US. Nor was it uncommon for US funding to reach Sweden. ${ }^{28}$ A substantial part of this funding went to reproductive research, a research area in which Sweden distinguished itself due to the comparatively liberal laws on abortion at the time. ${ }^{29}$ Research on abortion material had been publicly discussed in Sweden in the 196os, and the ethics of the use of this material had been debated. Reproductive research also came to play a role in political discussions about ethical aspects of biomedical research and the further development of research ethics reviews in the 1970s, a subject to which we will return later.

25 Jenny Hazelgrove, "The Old Faith and the New Science: The Nuremberg Code and Human Experimentation Ethics in Britain, 1946-73," Social History of Medicine, 15 (2002): 109-135.

26 Rolf Luft, "Medicinsk-etisk kommitté - ks var föregångare," in Karolinska sjukhuset 1940-1990: en minnesbok, ed. Bengt Pernow (Solna, 1990), 161-162; Sighild Westman-Naeser, "Current Experiences in the Nordic Countries," in Good Clinical Practice and Ethics in European Drug Research, ed. Peter Bennett (Bath, 1994), 27-35.

27 Luft, "Medicinsk-etisk kommitté," 161-162.

28 Solveig Jülich, "Fosterexperimentens produktiva hemlighet: Medicinsk forskning och vita lögner i 1960- och 1970-talets Sverige," Lychnos (2018): 10-49.

29 Ibid.; see also Helena Tinnerholm Ljungberg, "The Moral Imperative of Fetal Research: Framing the Scientific Use of Aborted Fetuses in the 196os and 1970s," in Medicine at the Borders of Life: Fetal Research and the Emergence of Ethical Controversy in Sweden, ed. Solveig Jülich (forthcoming); and Per-Anders Svärd and Helena Tinnerholm Ljungberg "Fetal and Animal Research in Sweden: The Construction of Viable Lives in Regulatory Policy Debates, 1970-1980," Studies in History and Philosophy of Science (forthcoming). 
By introducing the Declaration of Helsinki, the Nuremberg Code, and the publications by Beecher, a few steps had been taken towards a more collective responsibility for the ethics of biomedical research. The advanced notion of the development in this direction in the US had served as a backdrop for these first steps. However, the more immediate impulse that led to the formalization of the REC s came in the form of demands from the American NIH in its capacity as a research funder. ${ }^{30}$

1966-1967: Set up Phase: the Ethics Committee at the Karolinska Institute

As noted in the Introduction, the first formal REC in Sweden was set up at the Karolinska Institute in 1966, as a direct response to new demands from the US PHS that all research financed by the NIH had to undergo ethical assessment by a local committee. ${ }^{31}$ We here examine this process at the Karolinska Institute, both to illustrate the importance that they ascribed to these new demands, and because this committee came to be seen as a model for other committees around Sweden.

On 16 June 1966, the medical faculty at the Karolinska Institute appointed four members to an ad hoc committee to initiate the process of meeting the NIH's demands. Three professors, were appointed, along with one associate professor acting as secretary. In September, four additional professors joined the ad hoc committee. ${ }^{32}$ A month later, all eight were appointed as members of a fully formalized committee that would allow the institute to fulfil the requirements to keep their grants and to be eligible for new ones. ${ }^{33}$ By the winter of 1966/67 the head of both the medical faculty and of the newly established REC, Professor Torgny Sjöstrand, could give assurances to the US PHS that, the Karolinska Institute was in compliance with its 1 July 1966 ethics review policy. ${ }^{34}$

30 See Hedgecoe, "A Form of Practical Machinery," for an analysis of the importance of this new demand for the development of RECs in UK. Hedgecoe also drew attention to the similarities between UK and Sweden in this regard.

31 For a background to this development in the US, see Stark, Behind Closed Doors.

32 Extract from minutes from the faculty board meeting, 12 September 1966, A1:1, KIF KA, KIA, Solna.

33 Extract from minutes from the faculty board meeting, 13 October 1966. This decision was later confirmed by a decision in the Senate [konsistoriet] according to a copy of the decision from 1 January 1967. A1:1, KIFKA, KIA, Solna.

34 Torgny Sjöstrand (unsigned draft), "Institutional assurance on investigations involving human subjects, including clinical research," 29 December 1966, A1:1, KIFKA, KIA, Solna. 
In 1967, the discussions continued on how to best organize the review of research projects (with American funding). The ongoing correspondence between the PHS and the Karolinska Institute illustrated how important it was for the latter to comply with the new demands.

A few organizational aspects still needed to be clarified in this regard. One of these related to who was responsible for medical research. The Karolinska Institute specified in its first assurance to the PHS that Swedish regulations regarding medical research would clear the financier from any "legal responsibility or blame" in relation to any research project, stating instead that: "The principal investigator, who has outlined the project and received the grant has subsequently to get permission from the head of the clinic before the particular experiments are performed." 35 The PHs, however, was not satisfied with this first version and it was rejected by the Division of Research Grants in the spring of 1967. Renewed conversations on the safety of the human subjects followed, and in a letter to the professor of Pharmacology, PHs even formulated an amendment that could be directly included in the Karolinska Institute's assurance: "A reply substantially as follows would, I feel certain, be acceptable to our reviewers," special assistant Mordecai H. Gordon wrote, before specifying some of the measures that researchers should take to protect human research subjects. He also pointed out that the REC ought to make explicit reference to the use of the Declaration of Helsinki in their assessments. ${ }^{36}$ After another round of revisions to include these suggestions, the Karolinska Institute's assurance was finally accepted by the PHS in April $1967 .^{37}$

However, these amendments raised some questions among the members in the local REC. The issue was whether it was reasonable to assess only proposals financed by foreign funders or if projects funded by Swedish financiers should also be assessed. One committee member opined that it would be unnecessary to assess Swedish-funded experiments since Swedish researchers were already in compliance with the ethical guidelines: "The American missive is so moderate that one wonders if their recommendation is not always followed [here]."38 Another member claimed, matter-of-factly, that in only a few years all applications would be handled by committees anyway, implying that the reform might as well be adopted immediately. Sjöstrand summarized the discussion

35 Torgny Sjöstrand (unsigned draft), "Institutional assurance on investigations involving human subjects, including clinical research," January 1967, A1:1, KIF KA, KIA, Solna.

36 D. T Ch?? [handwriting unclear] (For Mordecai H. Gordon) to Dr. Bo Holmsted, 17 March 1967, A.1:1, KIF KA, KIA, Solna.

37 Torgny Sjöstrand, "Complementary institutional assurance," 10 April 1967 and Letter from Eugene A. Confrey to Torgny Sjöstrand, PHS, 27 April 1967, A1:1, KIF KA, KIA, Solna.

38 Minutes from the ethical committees meeting on 10 April 1967, A1:1, KIF KA, KIA, Solna. 
by stating that he would sign the amendment and that the committee would take a stand on domestically financed research later.

But before Sjöstrand and the other members of the Karolinska Institute's REC had time to address this question, a debate erupted on the ethical soundness of a study that was presented in a thesis defended at the Karolinska Institute. In May 1967, the issue of the limits of the responsibility of the newly established REC was actualized by the internal and external debates triggered by this new doctoral dissertation from the department of psychology. The discussion centred on the ethical appropriateness of showing uncensored, violent movies to under-aged children in psychological research. The dissertation and the research upon which it was based had also been described and questioned in national media. ${ }^{39}$ Moreover, the case led to debate within the Karolinska Institute where it came to serve as an example of the use of "one set of norms" in certain cases (i.e., research financed by $\mathrm{NIH}$ ) and another set of norms for research financed by other means. ${ }^{40}$ The faculty, argued Gunnar Biörck, needed to make a statement about whether the dissertation was acceptable or not. Biörck was the Professor of Cardiology. Having previously been a member of the REC, he served as an extra opponent at the dissertation defence. Other voices went further and claimed that the thesis should not be approved, since it "could not be acceptable from an ethical viewpoint." ${ }^{11}$ One member of the REC, the Psychiatry Professor Börje Cronholm, argued that one should make "a principled distinction between the ethical and the scientific assessments," meaning that a thesis should not be failed on ethical grounds alone. ${ }^{42}$ Cronholm also insisted that it would not be fair to retroactively apply the current ethical standards to judge a research project that had been planned before these standards had been established. Moreover, he contended that individuals ought not to be allowed to raise complaints against other researchers directly to the ethics committee. Instead, he proposed that they should turn to the medical faculty, which could remit such cases to the committee if they found it appropriate. Such accusations, he argued, could have "other motives than purely ethical". ${ }^{43}$ Cronholm concluded that this example had shown the "difficulty of interpreting the voice of the conscience, the codex ethicus and the Helsinki declaration" and pleaded for a "reasonable tolerance towards other

\footnotetext{
39 See also "Starka filmer ökar ej barnens aggressivitet," Dagens Nyheter, 13 May 1967.

40 Letter to the Dean of the Karolinska Institute from Gunnar Biörck, 16 May 1967, A1:1, KIF KA, KIA, Solna.

41 Cronholm was here referring to "Prosektor" Gyllensten in this regard. Memo "till medicinska fakulteten" from Prof. B Cronholm, 25 May 1967, A1:1, KIFKA, KIA, Solna.

42 Ibid., 2.

43 Ibid.
} 
researchers". ${ }^{4}$ This debate, again, illustrated some of the core themes of the time in the medical community's deliberations about the role and function of the ethical review system - the inclination to separate scientific merits from moral ones, the stout defence of scientific freedom, and a lingering fear of false accusations.

After the establishment of the REC at the Karolinska Institute, other medical faculties followed suit and set up local committees or ad hoc committees of their own. For example, committees were up and running at the medical faculties in Stockholm, Lund, Gothenburg, Uppsala and Umeå by the autumn of $1969 .{ }^{45}$ In the years that immediately followed, the focus in the medical community was to coordinate this work. During these years, referring to the established REC system could also be a way to counteract criticism aimed at medical researchers and their ethical awareness.

On 20 September 1969, a meeting was held with representatives from ssm's Ethics Delegation, a working group on ethical questions from the SMRC, as well as representatives from the medical faculties (wherever ethical committees had already been formed, the head of the committee represented that faculty). ${ }^{46}$ This meeting produced guidelines for the future cooperation among the REC s on questions of medical research and experiments on human subjects. The present parties agreed to assign the task of the assessment of research projects to local RECs at the medical faculties. The committees' decisions should only be advisory, however, and subjecting research proposals to review by committee would not be mandatory. In this regard, the meeting minutes are suggestive of an attempt to strike a balance between too much or too little ethical review. The committees should have a mandate to "intervene spontaneously if conditions are brought to their attention that are considered to justify an intervention". ${ }^{47}$ At the same time, the participants at the meeting stressed "that the institutionalization of medical ethical committees should not lead to unnecessary bureaucratization or inappropriate surveillance on a

\footnotetext{
44 Ibid., 3 .

45 Minutes from meeting at the SSM regarding ethical committees, 20 September 1969, F4:1, 1968-1970, Handlingar rörande bakgrund och bildande, Forskningsetiska Kommittén (FK), Göteborgs universitets arkiv (GUA), Göteborg.

46 Ibid.

47 Ibid., 2.
} 
collegial level."48 Among the advantages of this new ethical review system, it was mentioned that it would encourage the individual researcher (who was also pointed out as the responsible actor in the last instance) to reflect more on ethical issues. Still, the meeting seemed to assume that this kind of reflection ought to remain an intra-professional concern. In fact, it was argued that a review system implemented by the medical profession could "possibly prevent an otherwise imaginable intervention from laymen or government agencies with accompanying legislation." ${ }^{49}$ And in fact, the REC system would soon enough be used to defend the medical community from outside criticism.

\subsection{Handling Criticism from the Patients Association with Reference to the REc System}

In the international research on the history of medical ethics, the impact of the Patients Associations as a potential driving force has been analysed. ${ }^{50}$ In 1970, the Swedish Patients Association entered the discussion. Like their British counterpart, they took an interest in the question of informed consent and problematized the unequal power relation between patients and doctors. ${ }^{51}$ The association's legal advisor, Allan Bernståhle, held a lecture at the Second World Meeting on Medical Law in the United States in August, and later sent a copy to Gustav Giertz, head of the ss m's Ethics Delegation. A translated version was published in Läkartidningen along with a comment from Giertz. When the British Patients Association had voiced their concerns in the British Medical Journal, they had been supported by the editors. ${ }^{52}$ Läkartidningen, however, did not respond in the same manner. In a letter to Giertz, Sven Forsse (editorin-chief at the Läkartidningen), accounted for how the editors had decided to publish the article "after some internal discussions," and that they thought it be best if it was followed by an immediate answer from someone like Giertz. ${ }^{53}$ The stated argument behind their decision was that they preferred to see a debate on a "more balanced level" in their own journal than in the daily press. ${ }^{54}$

48 Ibid.

49 Ibid., 3. In October, the participants met again to formalize the discussion from their first meeting, and to decide on the division of responsibilities on research ethics between the local ethics committees at the faculties, the Ssm's Ethics Delegation and the SMrC; see Minutes from meeting at the SSM, 22 October 1969, F4:1, 1968-1970, Handlingar rörande bakgrund och bildande, FK, GUA, Göteborg.

50 Hedgecoe, "A Form of Practical Machinery."

$51 \quad$ Ibid., 337.

52 Ibid., 334 .

53 Sven Forsse to Gustav Giertz, 29 October 1970, Handlingar från Gustav Giertz (hereafter: Ö4):9, Binder 4, Svenska Läkaresällskapet (hereafter: SLS), TAM-Arkiv, Stockholm.

54 Ibid. 
Bernståhle's claims on behalf of the patients were that ethical principles should be regulated in law and that doctors had to make do with healthy volunteers: "Since, in my opinion, there is no 'lawful game' among healthy or sick children or among hospital patients, prisoners, medical students or other people in this particular position of dependence, the doctor must resort to using other mentally healthy subjects who can give informed consent."55 Giertz countered these claims by referring to the general work that the medical community had performed in the last couple of years, including the current work in the Ethics Delegation on the principles of the Declaration of Helsinki, and the development of the REC s. ${ }^{56} \mathrm{He}$ also stated that it was necessary for doctors to be able try new clinical practices, otherwise medical progress would come to a standstill. Moreover, his view of the relationship between patient and doctor differed significantly from that of Bernståhle. According to Giertz: "One should not forget, when assessing these matters that the doctor's and patient's interest most often coincide". ${ }^{57}$ In this response to the Patients Association's claims, REC s came to illustrate that the medical community had already taken the necessary actions to protect human research subjects.

1971-1975: Increased Demands for Ethical Review by Research Funders and Politicians

In the first half of the 1970s, the REC system grew steadily, and so did the political interest in several aspects of medical research development which in turn led to discussions in the Swedish parliament during this period, touching upon aspects of protecting research subjects and the integrity of the individual. On the one hand, there were calls to restrict or even forbid foetal research, and on the other, there were those who defended academic freedom and who sought to maintain trust in the medical community by referring to the new practices including REC s and their assessment of new research projects.

55 Allan Bernståhle, "Human experimentation - informed consent," Ö4:9, Binder 4, SLs, TAM-Arkiv Stockholm -original in English; also published in Swedish: Allan Bernståhle, "Medicinska experiment - informerat medgivande," Läkartidningen, 68 (1971): 341-343.

56 Gustav Giertz, "Medicinska experiment - en kommentar," Läkartidningen, 68 (1971): 344345 , here 344 .

57 Ibid. Giertz had also visited a meeting held by the Patients Association in December 1970 and wrote in his own memorandum that: "If I understood Bernståhle correctly, the Patients Association has about 180 members. The meeting was visited by maybe $5^{\circ}$ persons of which most were poor [stackars] people that had not found help within our medical organization and that were generally bitter towards society and came forward to bear witness about all their worries, complaints, and aches and pains." Gustav Giertz, Memorandum from meeting at the Patient's Association, 2 December 1970, Ö4:9, Binder 4 SLS, TAM-Arkiv, Stockholm. 
In January 1971, the SMRC had developed their own praxis on research funding and ethics. ${ }^{58}$ They did not yet require ethical pre-approval by committee. Only in cases when a member, in either one of the assessment committees (working groups within the SMRC set up to approve research grants) or the Council, expressed concern about the ethical status of an application would it be remitted to a local ethics committee. In a few cases this had led to the withdrawal of applications. By using this practice, "the Council contends that it has been given a guarantee that the best expertise is represented when it comes to assessing if something is questionable from an ethical point of view."59 Only about a month later, this praxis was changed and on 29 March 1971 the Ethics Delegation was informed about the ongoing work within the SMRC, which aimed to demand that all their financed research projects including human subjects should be subjected to prior ethical review by committee from 1972 and onwards. ${ }^{60}$

Around the same time, research ethics emerged as a hot political issue on the parliamentary agenda. At the beginning of the 1970s, the Swedish constitution was rewritten. In this process, two political parties (the agrarian Centerpartiet and the liberal Folkpartiet) suggested that it should be a constitutional right not to be "submitted to medical experiment without consent". ${ }^{61}$ The proposal aimed to complement a paragraph that already prohibited torture. ${ }^{62}$ When the proposal was remitted to the ssm's Ethics Delegation, it was problematized at length. The Ethics Delegation found it "disturbing" that torture and medical experiments would be mentioned in close connection, since "medical research on patients is done to give them better care than what is possible with established methods." 63 The inclusion of medical experiments and consent among the constitutional rights was not favoured in the policy process, and it was not included in the final version of the new constitution. However, other political debates did arise that would impact the overall organization of ethical review.

One concern was that rapid development in medical research required more active involvement of the Swedish state. Liberal MP Kerstin Anér, for example, presented a couple of motions on this topic that caught the medical

$5^{8}$ Lars Werkö to Gustav Giertz, 11 January 1971, Ö4:19, Binder 24, SLS, TAM-Arkiv, Stockholm.

59 Ibid.

6o Minutes from meeting at the ssm's Ethics Delegation, 29 March 1971, A3b:1, Delegationen för medicinsk etik, SLS, TAM-Arkiv, Stocholm.

61 Mot. 1973:1880 i anledning av Kungl.Maj:ts propositon 1973:90 med förslag till ny regeringsform och ny riksordning m.m. Av herrarna Helén \& Fälldin, p. 8.

62 Ibid.

63 Gustav Giertz, Head of the ssm's Ethics Delegation to Konstitutionsutskottet, 3 May 1973, Ö4:3, Binder VI Fri- och rättigheter, sLs, TAM-Arkiv, Stockholm. 
community's attention in the early 1970s. In 1972, Anér wrote that the risks with new medical developments led her to the conclusion that "it was about time" to legislate "how and if these methods may be used, by whom, when, and on whom" and she argued that parliament should assign this task to a special working group. ${ }^{64}$ Among the procedures Anér problematized were methods for prenatal diagnosis already in use, but she also foresaw a medical development towards in vitro fertilization, surrogate pregnancy, prenatal sex-selection, and other phenomena. ${ }^{65}$ Parts of Anér's motion were republished and commented on in Läkartidningen, and it was later processed by the parliamentary committee on Health and Welfare. ${ }^{66}$ The committee had received opinions from, among others, the SMRC, the SSM, and the medical faculties through the Swedish higher education authority (Universitetskanslerämbetet), who came out almost unanimously in their rejection of Anér's proposal on further parliamentary actions. ${ }^{67} \mathrm{In}$ answering Anér's motion, the value of academic freedom was a central counterargument, but the newly established various organizations dealing with research ethics which all adhered to the principles stated in the Declaration of Helsinki were also highlighted to illustrate that the medical community had already taken appropriate steps to safeguard ethical conduct in research. ${ }^{68}$ The parliamentary Committee on Health and Welfare rejected Anér's suggestions of assigning a working group, and referred instead to the responsibility of the National Board of Health and Welfare ( $\mathrm{NBHW}$ ) to monitor developments in medical research, and parliament voted in favour of the committee's suggestion. ${ }^{69}$

Anér herself was also invited to a meeting by the Ethics Delegation in the autumn of 1972. According to the invitation, the purpose was to inform her about the Delegation's work..$^{70}$ Whatever was said during this meeting, it cannot have allayed Anér's fears about new medical developments, since she presented a new motion with similar demands in 1974. This time she added more specific claims for the regulation of foetal research and suggested that ssm's

64 Mot. 1972:24, Angående individens okränkbarhet. Kerstin Anér (Fp).

65 Ibid.

66 "Kerstin Anérs riksdagsmotion om individens okränkbarhet," Läkartidningen, 69 (1972): 5193-5196; "Riksdagsmotion om individens okränkbarhet," Läkartidningen, 69 (1972): 472; SoU 1972:39. Socialutskottsbetänkande $i$ anledning av motion angående individens okränkbarhet.

67 SoU 1972:39.

68 Ibid.

69 Ibid.

70 Urban Rosenqvist to Kerstin Anér, 15 August 1972, Ö4:3, Binder vi Fri- och rättigheter, SLS, TAM-Arkiv, Stockholm. 
Ethics Delegation or another suitable body should function as an alert group and formulate such guidelines. ${ }^{71}$ With this motion she drew attention to foetal research, an area within biomedical research that had received renewed public and political attention in the early $1970{ }^{72}{ }^{72}$ Foetal research, was also brought up in another motion from the same year, which demanded that research including "live foetuses" should be banned, until the new abortion law was in place (a law that had been under review since 1965). Moreover, the motion expressed concern that abortions were being postponed, in order to abort foetuses that were of a certain age suitable for research purposes. ${ }^{73}$

The two motions were handled by the parliamentary Committee on Education which carried out an investigation on foetal experiments and research ethics. The committee report, signed in November 1974, repudiated the charges that living foetuses were used and that abortions were deliberately delayed for research purposes. ${ }^{74}$ In their report, the Committee on Education referred to the medical community's own research ethics organization as a guarantee that unethical research could not be performed in Sweden. They concluded that an investigation into the work of the research ethics committees was already undertaken by the research community. ${ }^{75}$ This ongoing investigation was used in the debate as an example of the measures taken by the medical community to tackle the increased demands for external oversight into biomedical research practices. Moreover, the Committee used this ongoing investigation as an important reason not to interfere or propose any new regulations in law. ${ }^{76}$ But they did recommend as part of their proposal that the investigation should carefully consider including lay members. ${ }^{77}$

71 Mot. 1974:30, Angående individen okränkbarhet, Kerstin Anér (Fp).

72 For more background and further analysis of foetal research and value conflicts, see Jülich, "Fosterexperimentens produktiva hemlighet"; Solveig Jülich and Helena Tinnerholm Ljungberg, "Från medicinskt avfall till rättighetsinnehavare. Framväxten av värdekonflikter kring aborterade foster i Sverige," Tidskrift för genusvetenskap, 40 (2019): 33-54; Tinnerholm Ljungberg, "The Moral Imperative."

73 Mot. 1974:1364, Angående nyttjande av levande abortfoster inom forskningen, Nils Carlshamre (M).

74 Bet. UbU 1974:35, Utbildningsutskottets betänkande med anledning av motioner angående medicinsk forskning på abortfoster.

75 Bet. UbU 1974:35, 8. In October 1974, the SMRC and the Ethics Delegation instigated an investigation into the work performed by the RECs. Giertz was appointed to this task and worked on it for a few years before presenting his findings in the report De etiska kommittéernas verksamhet, Statens medicinska forskningsråd, Stockholm (1977). By then, however, the debate on foetal research had already subsided.

76 UbU 1974:35, 8.

77 Ibid. 
Historian of medicine Solveig Jülich has concluded that the debates on foetal research in the post-war decades came and went but never escalated into a full-blown scandal. During this period "knowledge of [foetal] research was sweeping back and forth, like waves" in Sweden. ${ }^{78}$ Even though the criticism aimed at foetal research did not significantly escalate, it did put the matter of research ethics on the parliamentary agenda. The parliamentary debates on foetal research did not lead to new legislation, but they had an impact on the organization of ethics review and arguably speeded up this process. ${ }^{79}$

In December 1974, a meeting was arranged at the NBHW to discuss establishing an "alert group." 80 The meeting was headed by the Board's DirectorGeneral Bror Rexed and included representatives from the NBHW and quite a few professors representing various academic hospitals - among them Biörck, Zetterström, and Giertz. The summary from the meeting made it clear that the NBHW had planned on calling to a meeting to discuss such an alert group, but had been forestalled by Anér's claim in her motion. ${ }^{81}$ Various aspects of both medical treatment and research were addressed and: "Several of the participants insisted that a clarifying statement by some authority would be in order, since people would not be satisfied with, or trust, researcher's statements. It could, in certain cases, perhaps be enough if an authoritative scientist made a statement." 82 Rexed concluded that the NB HW should continue to work on the possibility of establishing an alert group, and that the discussion at the meeting could serve as guidance. Furthermore, he thought that such a body should include lay members, and that it should cooperate with both the NBHW and the already existing REC s. ${ }^{83} \mathrm{He}$ also argued in favour of including lay members in the REC S. ${ }^{84}$

78 Jülich, "Fosterexperimentens produktiva hemlighet," 40.

79 This criticism in the parliamentary debates of the medical community regarding foetal research have interesting similarities with the British REC development around the same time. As Hedgecoe has shown, the Peel Advisory Group (which had been given the task of investigating foetal research in UK) played a part in developing the REC system in UK; see Hedgecoe "A Form of Practical Machinery". The Peel Report was also mentioned in the 1974 motion from Anér, as an example of a more far-reaching regulation of foetal research, including that it should be assessed by REC s; see Mot. 1974:30.

8o "Sammanfattning av överläggningen på Socialstyrelsen 1974-12-o6 angående individens okränkbarhet," Socialstyrelsen, Byrå SN 1, Byrådir. M. Thorén, Ö4:3, SLS, Tam-Arkiv, Stockholm.

81 Ibid., 2.

82 Ibid., 3 .

83 Ibid., 6 .

84 Ibid. 
Around the same time, a conference was arranged by the SMRC on research ethics, and representatives from the REC $s$ at the medical faculties and the SSM's Ethics Delegation were invited. The conference acknowledged the Committee on Education's call for prior ethical review of foetal research and stated that from now on all research including foetuses would be subjected to ethical review. It also proclaimed that every REC should include one lay member. ${ }^{85} \mathrm{As}$ a result of these deliberations, the SMRC recommended, at the beginning of 1975, that all medical research on humans (including patients and volunteers) should be ethically assessed by an REC, no matter who financed it. ${ }^{86}$ Moreover, they suggested that the SMRC working group on the coordination of the REC s would be assigned the task of presenting further guidelines on the matter. ${ }^{87}$

In the early 1970s, the apparatus of the REC s had successively grown and spread to the various medical faculties all over Sweden. The public and political interest had also grown, including an increased attention directed toward both progress in medical research and medical research ethics. By the end of the period, it was decided that all medical research projects including human subjects should be assessed by a committee.

Over the last half of the 1970s and in the early 1980s, the sSM's Ethics Delegation, and the SMRC continued their discussions about the organization and limits of the ethical review system. In the early 1980 s, the medical community was again discussing ways to make sure that the Swedish REC system complied with the new NIH's policies on research ethics. In April 1980, the SM RC's working group on the coordination of RECs discussed new anticipated recommendations and policies for projects funded by the NIH. The working group decided to respond to this by direct communication to "inform the NIH about the organization, sanctioned by the SMRC and Riksdagen, of the ethics committees in Sweden." 88 The SMRC working group also discussed other ways to meet these new recommendations, mentioning the possibility of circulating research

85 Notes taken by Henry Danielsson, assistant secretary, at a conference at the SMRC, 18 December 1974, Ö4:7, Binder XIV:2, SLS, TAM-Arkiv, Stockholm.

86 Memo from the SMRC, signed by Bengt Gustafsson, secretary and Ingwar Lennerfors, head of division, 7 April 1975, referring to a decision taken on 26 February 1975. Ö4:7, Binder XIV:2, SLS, TAM-Arkiv, Stockholm.

87 Ibid.

88 Meeting notes, SMRC's working group on the coordination of local ethics committees' activity, 10 April 1980. Ö4:19, SLS, TAM-Arkiv, Stockholm. 
proposals to other RECs rather than having them assessed at the researcher's home faculty and the possibilities to include more lay members in the REC s. ${ }^{89}$ Later the same year, the working group returned to the matter, and the head of the group, Ove Broberger reported that the NIH had faith and trust in the ways in which the Swedish ethics review system worked, and no re-organization was deemed necessary. ${ }^{90}$ In a sense, this renewed discussion with the NIH illustrates the success that the Swedish medical community could enjoy (both internationally and nationally) in the early 1980 s, having set up a new system that had proven useful in several ways, not the least by signalling to public and political forces (and critics) that they were proactively dealing with the potential ethical risks associated with medical research on human subjects.

\section{7}

\section{Conclusion}

What becomes apparent after analysing the birth of the Swedish medical ethics review system is, first and foremost, the initial importance of both international inspiration and coercive isomorphism. The importance of the NIH's demand for review by committee in the first years of the REC setup phase cannot be ignored. It is evident in the ongoing communications between the Karolinska Institute's REC and the US, that the former found it important to meet the new demands and qualify for research funding. The KI model then spread to the other Swedish medical faculties over the course of a few years. By arranging meetings with the heads of the local RECs, along with representatives from both the SSM and the NBHW, the SMRC soon took on a coordinating role in the system. Public trust emerged as one of the most valuable elements in this process, and was repeatedly drawn upon to protect the right to continued self-regulation and to escape governmental or laypersons' interference. Maintaining trust was seen as the key to staving off outside involvement and sustaining academic freedoms. The imperative to nourish public and political trust ultimately overrode the fears of bureaucratization and peer-surveillance.

The REC system, alongside the initiatives taken by the other ethics organizations at the SSM and the SMRC, thus fulfilled several political functions. First of all, it secured the researchers' right to apply for research funding from the US. Secondly, the REC s proved useful when various medical research practices

89 Ibid.

90 Meeting notes, SMRC working group on the coordination of local ethics committees' activity, 28 October 1980. Ö4:19, SLS, TAM-Arkiv, Stockholm. 
were criticized by the Patients Associations and by politicians, as they could be employed to signal that preventative or remedial actions were being taken.

The overall development in the late 196os and early 1970s was characterized by a slow but steady dissemination of the KI model, which meant that more and more research proposals (from various research funders) had to undergo review by committee. But this policy diffusion was also pushed forward by singular events like the debate over the ethical status of a thesis at the KI, and the national and political attention directed to the allegations of misconduct in foetal research. The attention directed to the latter research never turned into a full-blown research scandal, arguably due to successful crisis management. Nonetheless, the debates in parliament likely speeded up the process that led to the inclusion of lay members in the REC s and to ethics review of all medical research on human subjects, regardless of by whom it was funded.

\section{Acknowledgement}

This research has been financed by the Swedish Research Council (Dnr 2014-1749). 